\title{
PASTORAL ALÉM-FRONTEIRAS
}

\author{
João Paulo Santos *
}

"A migrasão alarga o conceito de pátria para além das fronteiras geográficase políticas, fazendo do mundo a pátria de todos!"(João Batista Scalabrini).

"Nãa é só questão de trabalfiar para os migrantes, mas de tornar o rosto da Igreja e da fumanidade mais conforme ao Projeto de Deus.

Toda a Igreja é assim desafiada positivamente pelo fenômeno da mobilidade fumana e convidada a emigrar de seus esquemas tradicionais para viver em plenitude a missionariedade" (Paulo VI).

" $\mathcal{A}$ fim de que a pastoral migratória seja uma pastoral de comunfião (...), é indispensável que entre as Igrejas de origem e aquelas de chegada das correntes migratórias se instaure uma intensa colaboração, que nasça em primeiro lugar da informação recíproca sobre tudo aquilo que seja de comum interesse pastoral. De fato, não se pode conceber que tais Igrejas não dialoguem nem se confrontem sistematicamente, grafas também a encontros periódicos, sobre os problemas que se referem a milfares de migrantes"(Erga Migrantes Caritas Christi, $n^{\circ} 70$ ).
A Conferência Nacional dos Bispos do Brasil (CNBB), diante do novo fato histórico da emigração dos brasileiros para o exterior e, motivada pela Conferência Episcopal Americana que propôs uma cooperação entre ambas para melhor atender aos brasileiros que migravam para os Estados Unidos, deu início, em 1996, à Pastoral dos Brasileiros no Exterior (PBE).

As atividades da PBE estabelecem-se em eixos bastante amplos. Em especial, cumpre destacar três:

$\sqrt{ }$ Envio de missionários brasileiros ao exterior - que recebem, em curso específico, preparação acerca da realidade migratória e presença missionária junto aos emigrados;

$\sqrt{ }$ Identificação e contato com as comunidades brasileiras nos mais diversos países, levando a solidariedade e a proximidade da igreja de origem e a repartição de responsabilidades sócio-pastorais com a diocese de chegada;

$\sqrt{ }$ Assessoramento jurídico, articulando igreja, governos e ONGs na cooperação em favor dos emigrados.

A missão da PBE centra-se na assistência religiosa, no cultivo da fé. Em seu sentido amplo, na atividade com os brasileiros emigrados, a missão religiosa significa, primeiro, levar o Evangelho inculturado que os remete à diversidade brasileira em suas raízes afro, lusa e indígena, reforçando a dignidade e a autoestima. E, segundo, na linha do antropocentrismo pastoral pregado pós-Vaticano II, caminhar lado a lado com as dificuldades cotidianas destes seres humanos, percebendo suas dificuldades perante políticas migratórias restritivas, empobrecimento, desemprego, discriminações culturais, exclusões xenófobas e até mesmo criminalização dos migrantes.

Manter uma comunidade viva e seus membros com uma vida digna supõe primeiramente uma luta pela abertura das fronteiras e de mentes, ao mínimo ético do humanismo. Formas restritivas de políticas migratórias que rotulam o trabalhador estrangeiro de terrorista não podem ser toleradas no atual paradigma de direitos humanos que o mundo vive. Todos os terroristas do 11 de setembro eram residentes "legais". Nenhum refugiado. Nenhum "indocumentado". Criminalizar a mobilidade humana é talvez uma das formas mais aparentes dos países retirarem direitos dos migrantes e fomentar, cada vez mais, a xenofobia. Não haverá dignidade para esses nossos irmãos enquanto o fato de quererem trabalhar dignamente para sustentar suas famílias for razão de perseguição e exclusão. Efetivar instrumentos internacionais que protegem famílias de trabalhadores (destacamos aqui, a Convenção Internacional para a Proteção dos Direitos de todos os Trabalhadores Migrantes, aprovada em 1990 pela ONU) e diferenciá-los de criminosos e terroristas é a pedra angular de qualquer pastoral que efetivamente cuide e se preocupe com nossos irmãos que estão longe da pátria, da família, da própria terra. 


\section{Flashes}

- Consta da programação da PBE a realização de, no mínimo, duas visitas anuais, por parte de seu representante maior - o Bispo D. Laurindo Guizzardi (Diocese de Foz do Iguaçu/PR) junto aos locais de destino dos brasileiros no exterior. Cite-se, também, que recentemente, (julho de 2006), O Secretário Geral da CNBB e Bispo Auxiliar de São Paulo, D. Odilo Pedro Scherer esteve visitando o Japão.

- A PBE já enviou 23 missionários para as regiões de maior concentração de brasileiros no exterior, a saber: Estados Unidos, Japão, Canadá, Inglaterra, Itália e Portugal. Via de regra, o período de missão estende-se por três anos. Além disso, intensificam-se cada vez mais missões temporárias em períodos de férias e/ou em ocasiões especiais, como da Festa de Nossa Sra. Aparecida.

\section{- Em 2002 aconteceu o Primeiro}

Encontro Ibérico da Comunidade de Brasileiros no Exterior, em Lisboa, em parceria entre a Procuradoria Geral da República e a PBE, por parte do Brasil, e Casa do Brasil em Lisboa, Cáritas de Portugal e Obra Católica Portuguesa de Migrações, por parte de Portugal, do qual também participaram deputados e integrantes das Representações Diplomáticas de ambos os países.

\section{- Desde 2000 a PBE conta com o}

Boletim Eletrônico bimensal "Além

Fronteiras", disponível no site

www.migrante.org.br

\section{- A PBE, que tem na sua Presidência D.}

Laurindo Guizzardi, integra a Comissão Episcopal para a Ação Missionária e

Intereclesial e atua em articulação e integrada às Pastorais da Mobilidade Humana, da CNBB, e conta com a importante colaboração do Instituto Migrações e Direitos Humanos/ Brasília, do qual é diretora a Ir. Rosita Milesi mscs.
Lembramos que a efetivação desses direitos fundamentais passa pela organização e pela participação política da comunidade no país de residência, a qual deve ser sempre estimulada e fomentada pelas pastorais. Passa, sim, pela participação cada vez mais concreta e atuante das embaixadas e consulados brasileiros na defesa de seus cidadãos como também pela intervenção política dos próprios emigrados. Tal atitude simboliza um conceito de que a preocupação evangélica pastoral significa uma preocupação real com a cidadania dos fiéis em todas as esferas.

A greve de fome realizada por um movimento de brasileiros encarcerados no condado de Suffolk (EUA) mostra que, pouco a pouco, a consciência política pode começar a oferecer resultados para que a dignidade mínima possa ser respeitada, e que tais reações podem se tornar mais bem-sucedidas ao longo do tempo ${ }^{1}$.

Ressalte-se, ainda, a importância e a abrangência dos serviços religiosos propriamente ditos que a PBE ajuda a realizar junto e com as comunidades brasileiras em diferentes países. A religiosidade, quando se está longe de casa, adquire uma importância psicológica e emocional muito maior. Parte do ministrar os sacramentos para ir muito além, refazendo memórias e celebrando identidades culturais que ficaram distantes, no país de origem, no saudoso Brasil.

A religião passa a oferecer não só serviços litúrgicos, mas uma liturgia sacramental da vida, como se depreende do relato de uma participante da comunidade em Chicago:

"De 1994 até agora a comunidade cresceu, tivemos outras lideranças e aos poucos os brasileiros perceberam não só a importância de ter a missa celebrada em português, mas a preciosidade de poder estar juntos com seus conterrâneos, tomar um chimarrão, comer uma boa feijoada, um churrasco gaúcho, dançar, enfim a preciosidade de ser acolhido com muito calor humano num lugar tão 'frio' como Chicago" (Isaura Maria da Costa Crump - Boletim Além Fronteiras, 23, jul-ago/04).

Ou seja, o chimarrão, a dança, a conversa, a língua portuguesa, não são mais somente o que são, mas remetem a histórias de vida, a relações afetivas, a lembranças da presença de seus familiares e de Deus em suas vidas, se transformando, imediatamente em ferramentas que dão coragem para enfrentar a frieza e a batalha árdua com que se deparam nos novos países.

Em resumo, a PBE busca ser e levar, principalmente através das missionárias e missionários, assistência religiosa e apoio nas demandas sociais, econômicas e políticas dos emigrados. Ser co-responsável pela memória religiosa, cultural e identitária de nossos irmãos que estão longe, refazer-se como Igreja, conforme nos indica a frase do papa Paulo VI.

Assim, privilegiando o cuidado acima de qualquer barreira e indo além das fronteiras, a meta é construir uma pastoral transnacional que prove, concretamente, que a fraternidade e a boa notícia outrora pregadas por Jesus de Nazaré estão além de todos os limites que sociedades e governos tentem construir.

\footnotetext{
* Advogado de movimentos populares, assessor juridico do Instituto Migrações e Direitos Humanos, Brasilia, e colaborador nas Pastorais da Mobilidade Humana, da CNBB.
}

1 - Vide reportagem de Laura Capriglione "Estranhos no Paraíso", publicada na Folha de São Paulo, Caderno Cotidiano, em 10/02/06. Trata de Fernando de Sá Lima Monteiro, 20, e Rogério Zanotelli, 27, que iniciaram uma greve de fome para reivindicar condições carcerárias melhores, por estarem presos contrariamente a convenções da ONU sobre migrantes. Infelizmente, esse primeiro movimento está tentando ser abafado pelo isolamento de ambos como castigo. Todavia, o desfecho ainda está em aberto. 